\title{
EFEKTIVITAS PEMBELAJARAN ILMU RESEP DI SMK BIDANG KEAHLIAN FARMASI DI KABUPATEN CILACAP
}

\author{
Hendri Hermawan \\ SMKN 2 Simpang Empat, Tanah Bumbu, Kalimantan Selatan \\ hendri.abine.farras@gmail.com
}

Abstrak

Penelitian ini bertujuan untuk mengetahui: (1) Efektivitas pembelajaran ilmu resep di SMK bidang keahlian farmasi di Kabupaten Cilacap, dan (2) Pengaruh kompetensi profesional guru, pengelolaan kelas dan sarana prasarana pembelajaran dengan efektivitas pembelajaran ilmu resep pada siswa SMK bidang keahlian farmasi di Kabupaten Cilacap. Populasi seluruh siswa SMK bidang keahlian farmasi kelas XI di kabupaten Cilacap. Pengumpulan data menggunakan angket dengan model skala likert dan rating scale. Teknik analisis data yang digunakan adalah analisis deskriptif, analisis regresi sederhana dan analisis regresi ganda pada taraf signifikansi 5\%. Hasil analisis deskriptif menunjukkan bahwa efektifitas pembelajaran ilmu resep di SMK bidang keahlian farmasi di Kabupaten Cilacap berada pada kategori sangat baik. Hasil analisis regresi ganda menunjukkan bahwa terdapat pengaruh yang positif secara bersama-sama kompetensi profesional guru, pengelolaan kelas dan sarana prasarana pembelajaran terhadap efektivitas pembelajaran ilmu resep di SMK bidang keahlian farmasi di Kabupaten Cilacap dengan koefisien korelasi 0,521 dengan $F_{\text {hitung }}=15,497$ dan sumbangan efektif $27,1 \%$.

Kata kunci: efektivitas pembelajaran, ilmu resep, bidang keahlian farmasi

\section{THE EFFECTIVENESS OF PRESCRIBING SCIENCE LEARNING AT PHARMACY SKILL PROGRAM OF VOCATIONAL HIGH SCHOOL IN CILACAP REGENCY}

\author{
Hendri Hermawan \\ SMKN 2 Simpang Empat, Tanah Bumbu, Kalimantan Selatan \\ hendri.abine.farras@gmail.com
}

\begin{abstract}
This study aims to reveal: (1) the effectiveness of prescribing science learning at pharmacy skill program of vocational high school in Cilacap Regency, and (2) the effect of teacher's professional competency, class management and educational facilities and infrastructures on the effectiveness of prescribing science learning at pharmacy skill program of vocational high school in Cilacap Regency. The population is all grade XI students of the pharmacy skill program of vocational high schools in Cilacap Regency. The data were collected by means of questionnaires with the Likertscale model and rating scale. The data were analyzed using the descriptive, simple regression, and multiple regression analysis at a significance level of 5\%. The results of the descriptive analysis show that the effectiveness of perscribing science learning at pharmacy skill program of vocational high school in Cilacap Regency is in the very good category. The result of the multiple regression analysis shows that there is a positive and significant effect of the teacher's professional competency, class management and educational facilities and infrastructures as an aggregate on the effectiveness of prescribing science learning at pharmacy skill program of vocational high school in Cilacap Regency with a correlation coefficient of 0.521 with $F_{\text {observed }}=15.497$ and an effective contribution of $27.1 \%$.
\end{abstract}

Keywords: effectiveness of learning, prescribing science, pharmacy skill program 


\section{PENDAHULUAN}

Sistem pendidikan di Indonesia belum mampu untuk menyediakan sumber daya manusia yang memiliki daya saing tinggi. Hal ini dibuktikan dengan adanya laporan dari United Nation Educational, Scientific, and Cultural Organization (UNESCO), Badan Perserikatan Bangsa-Bangsa yang mengurus bidang pendidikan. Menurut Badan PBB itu, peringkat Indonesia dalam bidang pendidikan pada tahun 2007 adalah 62 di antara 130 negara di dunia. Education Development Index (EDI) Indonesia adalah 0,935, di bawah Malaysia $(0,945)$ dan Brunei Darussalam $(0,965)$. Selain itu juga hasil penelitian United Nation Development Programe (UNDP) pada tahun 2007 tentang Indeks Pengembangan Manusia menyatakan Indonesia berada pada peringkat ke-107 dari 177 negara yang diteliti Indonesia memperoleh indeks 0,728. Jika Indonesia dibanding dengan negara-negara ASEAN yang dilibatkan dalam penelitian, Indonesia berada pada peringkat ke-7 dari sembilan negara ASEAN. (http://netsains.com /2011/10/jaminan-mutu-dalam-sertifikasiguru)

Menurut Samsudi (2008:1) dalam E. Kosasih (2010:1), pada pidato Dies Natalis ke-43 Unnes mengatakan bahwa lulusan SMK seharusnya diserap oleh dunia kerja mencapai 80-85 \%. Tetapi kenyataannya, hanya $61 \%$ lulusan SMK yang dapat terserap oleh dunia kerja. Pada tahun 2006, dari lulusan SMK sebanyak 628.285 orang, hanya 385.986 orang yang dapat terserap oleh dunia kerja. Hal ini menunjukkan bahwa SMK belum mampu menyediakan pendidikan kejuruan yang baik bagi lulusannya.

Menurut Cox (2000:1), "The quality of an instructional program is comprised of three elements, materials (and equipment), activities and people". Kualitas dari sebuah program pembelajaran tergantung dari tiga unsur, yaitu peralatan (dan perlengkapan), kegiatan pembelajaran dan manusianya. Dalam hal ini dapat ditarik kesimpulan bahwa sarana prasarana, proses belajar mengajar dan sumber daya manusia sangat berperan penting bagi tercapainya sebuah pembelajaran yang berkualitas.

\section{Efektivitas Pembelajaran}

The Liang Gie dalam Ensiklopedi Administrasi (1989:108) mendefinisikan efektivitas sebagai berikut.

Suatu keadaan yang mengandung pengertian mengenai terjadinya efek atau akibat yang dikehendaki. Jika seseorang melakukan suatu perbuatan dengan maksud tertentu yang memang dikehendaki, maka orang itu dikatakan efektif kalau memang menimbulkan akibat dari yang dikehendakinya itu.

Pendapat Liang Gie di atas mengandung makna bahwa suatu kegiatan akan dikatakan efektif apabila kegiatan yang dilaksanakan tersebut berhasil mencapai tujuan yang telah ditetapkan. Dalam hal kegiatan belajar mengajar di sekolah, suatu proses pembelajaran akan dikatakan efektif apabila kegiatan proses belajar mengajar di sekolah tersebut berhasil mencapai tujuan yang ingin dicapai yang telah dirumuskan sebelumnya oleh sekolah.

\section{Kompetensi Profesional Guru}

Dalam Undang-Undang Nomor 14 Tahun 2005 tentang guru dan dosen dijelaskan bahwa kompetensi adalah seperangkat pengetahuan, keterampilan, dan perilaku yang harus dimiliki, dihayati, dan dikuasai oleh guru atau dosen dalam melaksanakan tugas keprofesionalan (E. Mulyasa, 2008: 25). Pendapat senada dikemukakan oleh Bond, R. \& Cone, C. (2012:20) mendefinisikan kompetensi, "Competence is defined as "the condition of being capable" to perform the duties of a profession." (kompetensi didefinisikan sebagai kondisi 'mampu' untuk melakukan tugastugas dari suatu profesi).

Kompetensi profesional guru dapat diartikan sebagai kemampuan dan kewenangan guru dalam menjalankan profesi keguruannya. Guru yang kompeten dan profesional adalah guru yang piawai dalam melaksanakan profesinya. Pendapat senada dikemukakan oleh Kidd dan Czerniawski (2010: 11) yang mengatakan,

The profesional teacher role is complex and contested. By'professional' it is often meant an organized body of people who have acquired specialized and systematic knowledge that puts them in a separate 
social standing from others who do not possess this specialized knowledge.

Pernyataan tersebut dapat dimaknai bahwa seorang guru yang profesional dapat diartikan sebagai orang yang telah memperoleh pengetahuan khusus dan sistematis yang menempatkan mereka dalam kedudukan sosial yang terpisah dari orang lain yang tidak memiliki pengetahuan khusus.

\section{Pengelolaan Kelas}

Djamarah (2002:194), menyatakan bahwa pengelolaan kelas adalah keterampilan guru untuk menciptakan dan memelihara kondisi belajar yang optimal dan mengembalikannya bila terjadi gangguan dalam proses pembelajaran. Pengelolaan kelas menurut Wragg (1996:8) adalah segala sesuatu yang dilakukan guru agar anak-anak berpartisipasi aktif dalam kegiatan pembelajaran, bagaimanapun cara dan bentuknya. Pendapat senada tentang pengelolaan kelas menurut Orlich, et al. (2007:172), "classroom management, the way teacher organizes, disciplines, and runs the class in order to ensure positive behavior conductive to learning, is a top concern of many experienced teachers". Pengelolaan kelas adalah cara bagaimana seorang guru mengorganisasi, mendisiplinkan dan menjalankan kelas dalam rangka menciptakan perilaku positif yang kondusif untuk belajar.

Dapat disimpulkan dari beberapa pendapat di atas bahwa pengelolaan kelas adalah kemampuan yang harus dimiliki oleh seorang guru untuk menciptakan suasana kelas yang nyaman dan kondusif untuk terlaksananya kegiatan pembelajaran dengan baik sehingga tujuan pembelajaran dapat tercapai.

\section{Sarana Prasarana}

Peranan sarana dan prasarana dalam keberhasilan proses pendidikan tidak dapat diabaikan begitu saja. Mulyasa (2008: 49) mengartikan sarana pendidikan sebagai peralatan dan perlengkapan yang secara langsung dipergunakan dalam menunjang proses pendidikan khususnya proses belajar mengajar, seperti gedung, ruang kelas, meja, kursi, serta alatalat dan media pengajaran. Sementara prasarana pendidikan adalah fasilitas yang secara tidak langsung menunjang jalannya proses pendidikan/pengajaran, seperti halaman, kebun, taman, tetapi jika dimanfaatkan secara langsung untuk proses belajar mengajar, seperti taman sekolah untuk pengajaran biologi, halaman sekolah sebagai sekaligus lapangan olahraga, komponen tersebut merupakan sarana pendidikan.

Menurut Tatang M. Amirin (2009:2), sarana pendidikan merupakan segala macam alat yang digunakan secara langsung dalam proses pendidikan, sementara prasarana pendidikan adalah segala macam alat yang tidak secara langsung digunakan dalam proses pendidikan. Dari pengertian sarana prasarana di atas, dapat dilihat tentang pentingnya peranan sarana prasarana pendidikan dalam rangka meningkatkan efektivitas pembelajaran dalam suatu lembaga pendidikan.

\section{METODE PENELITIAN}

Jenis penelitian ini ex-post facto, dimana penelitian yang dilakukan untuk meneliti peristiwa yang telah terjadi dan kemudian merunut ke belakang untuk menemukan faktor-faktor yang mungkin atas peristiwa yang diteliti. Penelitian ini termasuk penelitian deskriptif. Dilihat dari segi pendekatannya penelitian ini dikategorikan penelitian kuantitatif.

\section{Tempat dan Waktu Penelitian}

Penelitian dilakukan di tiga SMK bidang keahlian farmasi di Kabupaten Cilacap. Penelitian dilaksanakan bulan NovemberDesember 2012.

\section{Populasi dan Sampel Penelitian}

Populasi penelitian terdiri dari semua siswa kelas XI di 3 (tiga) SMK bidang keahlian farmasi di Kabupaten Cilacap sebesar 203 orang. Penentuan jumlah sampel dihitung dengan merujuk pada krejcie table (Sugiyono, 2011:128). Jumlah populasi sebanyak 203 orang dengan taraf signifikansi 5\%, maka akan diperoleh jumlah sampel sebanyak 129 orang. Jumlah sampel yang diambil untuk masing-masing sekolah diperlihatkan dalam tabel berikut ini. 
Tabel 1. Penelusuran Alumni SMK Kabupaten Sleman Tahun 2006-2010

\begin{tabular}{lcc}
\hline \multicolumn{1}{c}{ Nama sekolah } & Jumlah siswa & sampel \\
\hline SMK Farmasi YPIB Majenang & 80 & 51 \\
SMK Muhammadiyah I Cilacap & 69 & 44 \\
SMK YPE Sampang & 54 & 34 \\
\hline Jumlah & 203 & 129 \\
\hline
\end{tabular}

\section{HASIL PENELITIAN DAN PEMBAHASAN}

Hasil penelitian dibuat berdasarkan data variabel bebas yaitu kompetensi profesional guru $\left(\mathrm{X}_{1}\right)$, pengelolaan kelas $\left(\mathrm{X}_{2}\right)$, sarana prasarana $\left(\mathrm{X}_{3}\right)$ dan variabel terikat efektivitas pembelajaran ilmu resep (Y). Perhitungan analisis data menggunakan bantuan komputer program SPSS versi 16.0 for windows.

\section{Kompetensi Profesional Guru}

Data variabel kompetensi profesional guru diperoleh melalui angket dan dengan perhitungan statistik diperoleh mean $(\mathrm{M})=$ 87,22; median $($ Med $)=87$; modus $($ Mod $)=$ 83; simpangan baku $(\mathrm{SD})=6,98$; nilai minimum $=70$ dan nilai maksimum $=102$. Skor kompetensi profesional guru dikumpulkan dengan angket yang berjumlah 21 butir dengan rentang skor $1-5$, sehingga nilai minimum ideal sebesar 21 dan maksimum ideal 105. Untuk memperjelas analisis maka dilakukan pengkategorian ke dalam lima kelas berdasarkan nilai mean ideal (Mi) dan standar deviasi ideal (SDi) sebagai berikut:

Tabel 2.

\begin{tabular}{clc}
\hline No & Rentang skor & Kategori \\
\hline 1 & $\mathrm{X} \geq \mathrm{Mi}+1,5 \mathrm{SDi}$ ke atas & Sangat baik \\
2 & $\mathrm{Mi}+0,5 \mathrm{SDi} \leq \mathrm{X}<\mathrm{Mi}+1,5 \mathrm{SDi}$ & Baik \\
3 & $\mathrm{Mi}-0,5 \mathrm{SDi} \leq \mathrm{X}<\mathrm{Mi}+0,5 \mathrm{SDi}$ & Cukup baik \\
4 & $\mathrm{Mi}-0,5 \mathrm{SDi} \leq \mathrm{X}<\mathrm{Mi}-0,5 \mathrm{SDi}$ & Kurang baik \\
5 & $\mathrm{Mi}-1,5 \mathrm{SDi}<\mathrm{ke} \mathrm{bawah}$ & Tidak baik \\
\hline
\end{tabular}

Adapun nilai $\mathrm{Mi}=1 / 2(105+21)=63$, sedangkan nilai $\mathrm{SDi}=1 / 6(105-21)=14$. Berdasarkan pengkategorian yang telah disusun, disimpulkan bahwa kompetensi profesional guru dalam kategori sangat baik $(65,89 \%)$, dan dalam kategori baik $(34,11 \%)$.

\section{Pengelolaan Kelas}

Data variabel pengelolaan kelas diperoleh melalui angket dan dengan perhitungan statistik diperoleh mean $(M)=146,3$; median $(\mathrm{Med})=148 ;$ modus $(\mathrm{Mod})=153$; simpangan baku $(\mathrm{SD})=13,48$; nilai minimum $=113$ dan nilai maksimum $=173$. Skor pengelolaan kelas dikumpulkan dengan angket yang berjumlah 35 butir pernyataan dengan rentang skor $1-5$, sehingga nilai minimum ideal sebesar 35 dan maksimum ideal 175. Untuk memperjelas analisis maka dilakukan pengkategorian ke dalam lima kelas seperti yang disebutkan di atas. Adapun nilai $\mathrm{Mi}=1 / 2$ $(175+35)=105$, sedangkan nilai $\mathrm{SDi}=1 / 6$ $(175-35)=23,33$.

Dari hasil pengkategorian dapat ditarik kesimpulan bahwa kemampuan guru ilmu resep dalam melakukan pengelolaan kelas berada dalam kategori sangat baik $(73,64 \%)$ dan kategori baik sebesar 26,36\%.

\section{Sarana Prasarana}

Data variabel sarana dan prasarana diperoleh melalui angket dan dengan perhitungan statistik diperoleh mean $(\mathrm{M})$ sebesar 86,$25 ;$ median $($ Med $)=85 ;$ modus $($ Mod $)=$ 83; simpangan baku $(\mathrm{SD})=11,44$; nilai minimum $=65$ dan nilai maksimum $=130$. 
Skor sarana prasarana dikumpulkan dengan angket yang berisi 29 butir pernyataan dengan rentang skor 1-5, sehingga nilai minimum ideal sebesar 29 dan maksimum ideal 145. Untuk memperjelas analisis maka dilakukan pengkategorian ke dalam lima kelas berdasarkan nilai mean ideal (Mi) dan standar deviasi ideal (SDi) sebagaimana disebutkan di atas. Adapun nilai $\mathrm{Mi}=1 / 2(145+29)=87$, sedangkan nilai $\mathrm{SDi}=1 / 6(145-29)=19,3$.

Berdasarkan pengkategorian disimpulkan bahwa sarana prasarana berada dalam kategori cukup baik dengan jumlah responden sebesar $66,67 \%$, dalam kategori sangat baik sebesar 3,87\%, kategori baik $7,75 \%$, dan kategori kurang baik sebesar $21,71 \%$.

\section{Efektivitas Pembelajaran Ilmu Resep}

Data variabel efektivitas pembelajaran ilmu resep yang diukur dari nilai hasil pem- belajaran ilmu resep memiliki skor terendah 70 dan skor tertinggi 95. Hasil analisis menunjukkan bahwa nilai hasil pembelajaran ilmu resep memiliki rerata sebesar 76,07; simpangan baku sebesar 5,01; median sebesar 75; dan modus sebesar 70. Skor efektivitas pembelajaran diperoleh dari dokumentasi nilai ulangan harian ilmu resep semester gasal 2012/2013. Pengkategorian dilakukan berdasarkan nilai mean ideal (Mi) dan standar deviasi ideal (SDi) seperti disebutkan di atas. Adapun nilai $\mathrm{Mi}=1 / 2(100+0)=50$, sedangkan nilai $\mathrm{SDi}=1 / 6(100-0)=16,67$.

Berdasarkan pengkategorian diperoleh kesimpulan bahwa efektivitas pembelajaran ilmu resep berada dalam kategori sangat baik $(61,24 \%)$ dan kategori baik sebesar 38,76\% .

Hasil analisis regresi linier sederhana variabel bebas terhadap variabel terikat dapat dilihat pada Tabel 3 berikut ini.

Tabel 3. Kisi-kisi Angket

\begin{tabular}{cccccc}
\hline No & Variabel & R parsial & $\begin{array}{c}\text { Sumbangan } \\
\text { efektif }(\%)\end{array}$ & $\begin{array}{c}\text { Thitun } \\
\mathrm{g}\end{array}$ & $\mathrm{P}<0,05$ \\
\hline 1 & $\mathrm{X} 1$ & 0,416 & 17,3 & 5,150 & 0,000 \\
2 & $\mathrm{X} 2$ & 0,211 & 4,4 & 2,428 & 0,017 \\
3 & $\mathrm{X} 3$ & 0,407 & 16,6 & 5,028 & 0,000 \\
\hline
\end{tabular}

Berdasarkan tabel di atas nilai $\mathrm{T}_{\text {hitung }}$ ketiga variabel bebas $\left(X_{1}=5,150 ; X_{2}=2,428\right.$; $\left.\mathrm{X}_{3}=5,028\right)$ lebih besar daripada $\mathrm{T}_{\text {tabel }}$ pada df 25 dan taraf signifikansi 5\% sebesar 1,970 serta nilai sig. ketiga variabel bebas $\left(X_{1}=0,000 ; X_{2}=0,017 ; X_{3}=0,000\right)$ lebih kecil dari 0,05 maka hal ini berarti terdapat pengaruh yang positif dan signifikan antara masing-masing variabel bebas terhadap variabel terikat.

Hasil analisis regresi ganda menunjukkan bahwa nilai $F_{\text {hitung }}$ sebesar 15,497 dan nilai signifikansi $0,000(p<0,05)$. Nilai tersebut di atas nilai $\mathrm{F}_{\text {tabel }}$ untuk $\mathrm{N}=129$ yaitu sebesar 2,68 sehingga diinterpretasikan bahwa variabel kompetensi profesional guru, pengelolaan kelas dan sarana prasarana mempunyai pengaruh yang positif terhadap efektivitas pembelajaran ilmu resep. Selain itu berdasarkan hasil perhitungan diperoleh koefisien korelasi (R) sebesar 0,521 dan koefisien determinasi sebesar 0,271. Hal ini bermakna bahwa kompetensi profesional guru, kemampuan pengelolaan kelas dan sarana prasarana secara bersama-sama memberikan sumbangan efektif sebesar $27,1 \%$ atau dapat menjelaskan sekitar $27,1 \%$ variansi efektivitas pembelajaran ilmu resep.

Ketiga variabel bebas kompetensi profesional guru $\left(\mathrm{X}_{1}\right)$, kemampuan pengelolaan kelas $\left(\mathrm{X}_{2}\right)$ dan sarana prasarana $\left(\mathrm{X}_{3}\right)$ dapat masuk ke dalam persamaan regresi ganda atas variabel terikat efektivitas pembelajaran (Y) berdasarkan probabilitas nilai t. Koefisien regresi dan probabilitas t disajikan pada Tabel 4. 
Tabel 4. Kompetensi Koefisien Regresi Variabel Bebas terhadap Variabel Terikat

\begin{tabular}{cccc}
\hline Variabel & Koefisien regresi (B) & Nilai t & $\mathrm{P}<0,05$ \\
\hline Konstanta & 36,091 & 5,396 & 0,0000 \\
X1 & 0,208 & 3,445 & 0,001 \\
X2 & 0,078 & 2,336 & 0,021 \\
X3 & 0,121 & 3,304 & 0,001 \\
\hline
\end{tabular}

Berdasarkan tabel di atas terlihat besarnya nilai $\mathrm{b} 1=0,208 ; \mathrm{p}=0,001(\mathrm{p}<0,05)$; $\mathrm{b} 2=0,078 ; \quad \mathrm{p}=0,021 \quad(\mathrm{p}<0,05) ; \quad \mathrm{b} 3=0,121 ;$ $\mathrm{p}=0,001(\mathrm{p}<0,05) ;$ konstanta $(\mathrm{a})=36,091$. Sesuai dengan hasil di atas variabel $\mathrm{X}_{1}\left(\mathrm{~b}_{1}\right)$, $\mathrm{X}_{2}\left(\mathrm{~b}_{2}\right), \mathrm{X}_{3}\left(\mathrm{~b}_{3}\right)$ dapat masuk ke dalam persamaan regresi $\hat{Y}=36,091+0,208 X_{1}+0,078 X_{2}$ $+0,121 \mathrm{X}_{3}$. Model persamaan regresi tersebut memberikan gambaran bahwa ketiga prediktor dapat digunakan untuk memprediksi kriterium efektivitas pembelajaran ilmu resep. Hal ini bermakna bahwa efektivitas pembelajaran ilmu resep dipengaruhi oleh variabel kompetensi profesional guru, kemampuan pengelolaan kelas dan sarana prasarana.

\section{KESIMPULAN}

Berdasarkan analisis data dan pembahasan hasil penelitian dapt disimpulkan:

1. Efektivitas pembelajaran ilmu resep di SMK bidang keahlian farmasi di Kabupaten Cilacap berada pada kategori sangat baik dimana sebanyak $61,24 \%$ dengan kategori sangat baik, dan 38,76\% dengan kategori baik.

2. Terdapat pengaruh yang positif dan signifikan kompetensi profesional guru ilmu resep di SMK bidang keahlian farmasi di Kabupaten Cilacap terhadap efektivitas pembelajaran ilmu resep dengan besarnya koefisien korelasi parsial $r=0,416$ dan besarnya sumbangan efektif sebesar $17,3 \%$.

3. Terdapat pengaruh yang positif dan signifikan pengelolaan kelas terhadap efektivitas pembelajaran ilmu resep di SMK bidang keahlian farmasi di Kabupaten Cilacap dengan besarnya koefisien korelasi parsial $\mathrm{r}=0,211$ dan besarnya sumbangan efektif sebesar $4,4 \%$.

4. Terdapat pengaruh yang positif dan signifikan sarana prasarana terhadap efektivitas pembelajaran ilmu resep di
SMK bidang keahlian farmasi di Kabupaten Cilacap dengan besarnya koefisien korelasi parsial $\mathrm{r}=0,407$ dan besarnya sumbangan efektif sebesar 16,6 $\%$.

5. Terdapat pengaruh yang positif dan signifikan secara bersama-sama kompetensi profesional guru, pengelolaan kelas dan sarana prasarana terhadap efektivitas pembelajaran ilmu resep di SMK bidang keahlian farmasi di Kabupaten Cilacap dengan koefisien korelasi sebesar 0,521 dan besarnya sumbangan efektif ketiga variabel tersebut terhadap pembelajaran ilmu resep sebesar $27,1 \%$.

\section{DAFTAR PUSTAKA}

Anonim. (2011). Jaminan Mutu dalam Sertifikasi Guru. diambil pada tanggal 27 November 2011 dari http://netsains. com/2011/10/jaminan-mutu-dalamsertifikasi-guru/.

Bond, R. \& Cone, C. (2012). Improving Student Confidence in Skill Performance in a Pharmaceutical Care Lab Setting. Pharmacy Education, 2012; 12 (1): $20-24$

Cox, J. (2006). The Quality of An Instructional Program. National Education Association-Alaska. Diakses pada tanggal 23 Pebruari 2012, dari http: //www.ak.nea.org./excellence/coxqu ality

Djamarah, Syaiful B (2002). Strategi Belajar Mengajar. Jakarta: Rineka Cipta.

E. Kosasih Danasasmita. (2010). Preparing Graduates Who Are Ready To Work: Challenges And Solutions. Proceedings of the 1stUPI International Conference on Technical and Vocational Education 
and Training. Bandung, Indonesia. 1011 November 2010

E. Mulyasa. (2008). Menjadi Guru Profesional. Bandung: Remaja Rosdakarya

Gie, The Liang. (1989). Ensiklopedi Administrasi. Jakarta: PT. Air Agung Putra.

Kidd,W. \& Czerniawski, G. (2010). Successful Teaching 14-19, Theory, Practice and Reflection. London: Saga Publications Ltd.

Orlich, D.C., Harder, R.J., Callahan, R.C., et al. (2007). Teaching Strategies, A
Guide To Effective Instruction. USA: Houghton Mifflin Company.

Sugiyono. (2011). Metode Penelitian Pendidikan. Bandung: Alfabeta.

Tatang M. Amirin. (2011). Pengertian Sarana dan Prasarana Pendidikan. Diambil pada tanggal 11 Oktober 2011, dari http://www.tatangmanguny.wordpress.c om

Wragg, E.C. (1996). Pengelolaan Kelas (Edisi Terjemahan oleh Anwar Jasin). Jakarta: PT Gramedia Widiasarana Indonesia. 